\title{
A Study of Heavy Metal Accumulation in Sediments at Phuket Bay, Saphan Hin, Phuket Province
}

\author{
Kaimook Jaileak and Pensiri Akkajit
}

\begin{abstract}
The concentrations of heavy metals ( $\mathrm{Sn}, \mathrm{Pb}$, and Zn) were investigated in two sediment cores at Phuket bay, Phuket, Thailand. The analysis of heavy metal content was carried out by using aqua regia digestion and measured by using inductively coupled plasma optical emission spectrometer (ICP-OES). The concentrations of $\mathrm{Sn}, \mathrm{Pb}$, and $\mathrm{Zn}$ were ranged from 49.9 to $167 \mathrm{mg} \mathrm{kg}^{-1}, 9.6$ to $58.7 \mathrm{mg} \mathrm{kg}^{-1}$ and 45.4 to $144 \mathrm{mg}$ $\mathrm{kg}^{-1}$, respectively. The degree of pollution in sediments assessed by Geo-accumulation index $\left(I_{\text {geo }}\right)$ indicated that the sediment samples in this study were either not contaminated or moderately contaminated with $\mathrm{Zn}$ and $\mathrm{Pb}(-1.40$ to 0.26 and -1.24 to 0.97 , respectively). In addition, the accumulation of heavy metals was evaluated using Enrichment Factor (EF) and the results showed that sediment samples are minimal to significant enrichment from anthropogenic activity ( $\mathrm{Pb}$ and $\mathrm{Zn}$ : 1.6 to 6.2 and 2.1 to 6.9 , respectively).
\end{abstract}

Index Terms-Accumulation, enrichment factor, geo-accumulation, heavy metal, sediment.

\section{INTRODUCTION}

Currently, the aquatic environment problem has become a worldwide concern due to anthropogenic activities such as mining, industrial and urban has discharged wastewater directly into water resources that cause the impact on water quality [1], [2] such as the increased heavy metal level in aquatic environment [3]. The heavy metal contamination can affect human and living organisms due to their toxicity, persistence, non-degradability and accumulative behaviors [4]. Metal distribution in the aquatic environment can cause the adverse effects to human health because of food chain transfer. The main sources of the heavy metals in the aquatic environment are difficult to identify. Phuket is one of the provinces in the South of Thailand with the tin (Sn) mining

Manuscript received December 31, 2017; revised April 14, 2018. This work was supported by Faculty of Technology and Environment, Prince of Songkla University, Phuket Campus; Research Program of Toxic Substance Management in the Mining Industry, Center of Excellence on Hazardous Substance Management (HSM), Bangkok 10330, Thailand; Research Unit of Site Remediation on Metals Management from Industry and Mining (Site Rem), Chulalongkorn University, Bangkok 10330, Thailand.

Kaimook Jaileak is with the Faculty of Technology and Environment, Prince of Songkla University, Phuket Campus, Phuket 83120, Thailand (e-mail: mook_km23@outlook.com).

Pensiri Akkajit is with Integrated Science and Technology Research Center (Applied Chemistry/Environmental Management/Software Engineering), Prince of Songkla University, Phuket Campus, Phuket 83120, Thailand; Faculty of Technology and Environment, Prince of Songkla University, Phuket Campus; Research Program of Toxic Substance Management in the Mining Industry, Center of Excellence on Hazardous Substance Management (HSM), Bangkok 10330, Thailand; Research Unit of Site Remediation on Metals Management from Industry and Mining (Site Rem), Chulalongkorn University, Bangkok 10330, Thailand (e-mail: pensiri.a@phuket.psu.ac.th). industry is very popular in the past for the economic development [5]. Tin mining activities have released various metals and toxins to the nature basin without a pre-treatment, and therefore cause metal contamination in the water and sediment [6]. Bang-Yai canal is the main canal of Phuket that used mostly in the past for transportation. Bang-Yai canal is approximately 8,000 meters in length started from Kathu waterfall and ended at the seacoast of the Phuket bay in Saphan Hin at Muang Phuket district. It can be considered as the drainage area receiving many effluents from various community sources from Phuket Town such as old Sn mining ponds, domestic wastewater discharge, and boat parking areas [7]. Therefore, heavy metal accumulation of Lead (Pb), Tin and Zinc ( $\mathrm{Zn})$ in the coastal environment is of the interest in this research. The main objective of this study is to study the accumulation and contamination levels of heavy metals at Saphan Hin, Phuket province. The levels of heavy metal contamination in the area were evaluated by using enrichment factor $(\mathrm{EF})$ and geo-accumulation index $\left(\mathrm{I}_{\mathrm{geo}}\right)$ to assess the impact and contamination levels of heavy metals. The results of this research can be used in environmental impact assessment in the area in order to prevent the environmental impact caused by heavy metal pollution.

\section{MethodOLOGY}

\section{A. Sediment Core Sampling}

The study area is located at Saphan Hin, Phuket bay, Muang Phuket District, Phuket province. Sediment samples were collected in May 2017 during the lowest tide of 0.7 to 0.8 meters above the water level [8]. Two sediment cores were sampled namely point A (longitudes $7^{\circ} 52^{\prime} 7.10^{\prime \prime} \mathrm{N}$; latitudes $98^{\circ} 24^{\prime} 5.38^{\prime \prime} \mathrm{E}$ ) and point B (longitudes $7^{\circ} 52^{\prime} 3.88^{\prime \prime} \mathrm{N}$; latitudes $\left.98^{\circ} 24^{\prime} 4.50 " \mathrm{E}\right)$, respectively by Russian corer (100 $\mathrm{cm}$ in length and $12 \mathrm{~cm}$ in diameter) (Fig. 1). Each core was sub-sectioned at $5 \mathrm{~cm}$ intervals. There are totally 20 sediment layers for each sediment core (totally 40 sediment samples for Core A and B). All of the samples were stored in polythene bags, kept in the icebox at $4^{\circ} \mathrm{C}$ and brought to the laboratory immediately.

\section{B. Physicochemical Parameters}

Physicochemical parameters of the sediment samples in the two cores were determined on-site included sediment $\mathrm{pH}$, oxidation-reduction potential (ORP), and electrical conductivity (EC) (1:5 sediment/water ratio) by $\mathrm{pH}$ meter (Eutech version: Cyber scan Diamond Series pH 450) and EC meter (HM version: EC-3M), respectively. Sediment samples were digested following the EPA 3052 guideline [9]. The 0.5 $\mathrm{g}$ of dried sediment were digested with aqua regia $\left(\mathrm{HNO}_{3}\right.$ 
and $\mathrm{HCl}$ ) and analyzed by Inductively Coupled Plasma Optical Emission Spectrometry (ICP-OES) (Perkin Elmer Optima, 4300 DV/Perkin Elmer Optima 800). All glassware was cleaned using $\mathrm{HNO}_{3}(10 \%)$ followed by repeated rinsing with deionized water and dried in an electric oven prior to use. The accuracy of the analytical procedures for the analysis of heavy metals in sediment samples was checked using the certified reference material MESS-4 [10]. The results of recovery were $\mathrm{Zn} 104 \pm 6.7 \%$ and $\mathrm{Pb} 114 \pm 21.5 \%$, respectively.

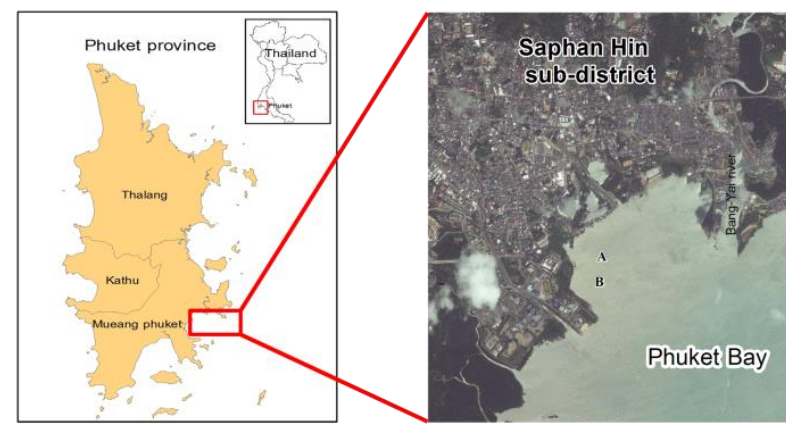

Fig. 1. Sampling sites of sediments at the Phuket Bay.

\section{Metal Pollution Level}

In order to evaluate the extent of the historical heavy metal pollution, an enrichment factor (EF) was used in this study [11] and calculated as follows;

$$
\mathrm{EF}=\left(\mathrm{C}_{\text {meta }} / \mathrm{Al}\right) \text { sample } /\left(\mathrm{C}_{\text {metal }} / \mathrm{Al}\right) \text { background }
$$

where $\left(\mathrm{C}_{\text {metal }} / \mathrm{Al}\right)$ sample is the concentration ratio of metal to $\mathrm{Al}$ in sediment cores and $\left(\mathrm{C}_{\text {metal }} / \mathrm{Al}\right)$ background is the average ratio of the same metal to $\mathrm{Al}$ in the background sample. The background concentrations of $\mathrm{Al}, \mathrm{Pb}, \mathrm{Zn}$ and $\mathrm{Sn}$ in Phuket Province used in this study are: $115,360 \mathrm{mg} \mathrm{kg}^{-1}, 20 \mathrm{mg} \mathrm{kg}^{-1}$, $80 \mathrm{mg} \mathrm{kg}^{-1}$, and $420 \mathrm{mg} \mathrm{kg}^{-1}$, respectively [12]. The EF values were interpreted as suggested by Department of pollution control (2012) [13] as if EF < 2 means deficiency to minimal enrichment, EF is between 2 to 5 means moderate enrichment, EF is between 5.01 to 20 means significant enrichment, EF is between 20.01 to 40 means very high enrichment, and EF > 40 means extremely high enrichment.

In addition, the Geo-accumulation Index $\left(\mathrm{I}_{\text {geo }}\right)$ was also calculated as criteria to evaluate the intensity of heavy metal contamination in the study area. The calculation is followed [14] as below:

$$
\mathrm{I}_{\text {geo }}=\log 2\left[\mathrm{C}_{\text {metal }}\left(\text { sample } / 1.5 \mathrm{C}_{\text {metal }}(\text { background })\right]\right.
$$

where $\mathrm{C}_{\text {metal }}$ (sample) is the concentration of a given element and $\mathrm{C}_{\text {metal }}$ (background) is the concentration of background value for the metal in sediments. The $I_{\text {geo }}$ values were interpreted as: $\mathrm{I}_{\text {geo }}<0$ unpolluted, $0<\mathrm{I}_{\text {geo }}<0.99$ unpolluted to moderately polluted, $1<\mathrm{I}_{\text {geo }}<1.99$ moderately polluted, $2<\mathrm{I}_{\text {geo }}<2.99$ moderately to strongly polluted, $3<$ $\mathrm{I}_{\text {geo }}<3.99$ strongly polluted, $4<\mathrm{I}_{\text {geo }}<4.99$ strongly to very strongly polluted, and $\mathrm{I}_{\text {geo }}>5.00$ very strongly polluted [13].

\section{Statistical Analysis}

Data analysis was done by using one-way analysis of variance (ANOVA) to indicate the significant differences among different sediment layer depths. All statistical analyses were computed by using SPSS version 16 .

\section{RESUlt AND Discussion}

\section{A. Physico-Chemical Properties}

The physicochemical properties of the sediment core samples are presented in Table I. It was found that sediment samples are neutral to very strongly alkaline in core $\mathrm{A}(\mathrm{pH}$ 7.2 to 9.1 ) and slightly alkaline in core $\mathrm{B}(\mathrm{pH} 8.1$ to 8.7). These results are consistent with the research in Bandon Bay, Surat Thani Province as the $\mathrm{pH}$ value of the sediments was ranged from 6.15 to 8.37 [15]. The $\mathrm{pH}$ value is an important parameter due to most of the chemical reactions in aquatic environment is controlled by any change in its $\mathrm{pH}$ value. Anything either highly acidic or alkaline would kill marine life [16]. It was known that high $\mathrm{pH}$ values enhance the precipitation of heavy metals through the formation of insoluble carbonates [17]. In addition, redox potential is an important parameter in environmental quality research. The mobility of heavy metals can also be limited due to the reducing conditions of the sediment [18] as it indicates the tendency of an environment to receive or give electrons. Redox potential, together with $\mathrm{pH}$, can be considered as one of a driving variable for speciation of heavy metals [19]. Soil oxidation and reduction depend on soil respiration, diffusion of oxygen, and carbon dioxide in soil and on changes in biochemistry of the system [20]. In this study, the redox potential values in core A and B are ranged from -131 to 59.9 $\mathrm{mV}$ and -117 to $122 \mathrm{mV}$, respectively. These values implied that the sediments in both of cores were oxidized and reduced form. The mobility of metals increases in low oxidation stage $(\mathrm{Eh}<100 \mathrm{mV})$ [21]. Heavy metals in the oxidation stage can be more mobile in the environment, however heavy metals in the reduction condition is immobile [22]. The results of this study consistent with another study in the U-Taphao canal, Songkla province found higher ORP ranged values of -221 to $406 \mathrm{mV}$ [23]. Electrical conductivity (EC) is another factor which affects the bioavailability of metals to plant [24]. It is controlled by the extent of soluble salts such as calcium, magnesium and sodium. In this study, the EC values in core $\mathrm{A}$ and $\mathrm{B}$ are ranged from 789 to $2626 \mu \mathrm{S} \mathrm{cm}^{-1}$ and 752 to $2495 \mu \mathrm{S} \mathrm{cm}^{-1}$, respectively. The sediments with high EC value are without of metals such as iron and zinc [25], and also sediment EC values more than $1000 \mu \mathrm{S} \mathrm{cm}^{-1}$ consist of highly conductive clays [26]. The results of this study consistent with the research in Chanthaburi Estuary found that EC values to be 3500 to $4000 \mu \mathrm{S} \mathrm{cm}^{-1}$ [27].

\section{B. Heavy Metal Concentrations in Sediment}

The heavy metal concentrations of $\mathrm{Sn}, \mathrm{Pb}$, and $\mathrm{Zn}$ in both sediment cores are presented in Table II. Metal contents in core a are as following; $\mathrm{Sn}$ : 49.9 to $167 \mathrm{mg} \mathrm{kg}^{-1}, \mathrm{~Pb}: 12.7$ to $44.5 \mathrm{mg} \mathrm{kg}^{-1}$, and $\mathrm{Zn:} 45.4$ to $88.0 \mathrm{mg} \mathrm{kg}^{-1}$. In sediment core $\mathrm{B}$, metal contents are as following: $\mathrm{Sn}: 77.5$ to $153 \mathrm{mg} \mathrm{kg}^{-1}$, $\mathrm{Pb}$ : 9.6 to $58.7 \mathrm{mg} \mathrm{kg}^{-1}$, and $\mathrm{Zn}: 59.9$ to $144 \mathrm{mg} \mathrm{kg}$. Suteerasak and Bhongsuwan (2008) [6] studied metal contamination of $\mathrm{Al}, \mathrm{As}, \mathrm{Cu}, \mathrm{Cr}, \mathrm{Mn}, \mathrm{Ni}, \mathrm{Pb}, \mathrm{Sn}, \mathrm{Zn}$ and $\mathrm{Fe}$ in 
sediment from Bang-Yai River in Phuket Province. They found high concentrations of $\mathrm{Zn}, \mathrm{Pb}, \mathrm{Sn}$ and $\mathrm{Al}$ (41-242 mg $\mathrm{kg}^{-1}, 17-113 \mathrm{mg} \mathrm{kg}^{-1}, 471$ to $15,174 \mathrm{mg} \mathrm{kg}^{-1}$ and 28,945 to $99,961 \mathrm{mg} \mathrm{kg}^{-1}$, respectively). Heavy metal concentrations in this study were compared with other sediment quality standards (Table III.). It was found that metal concentration was less than the Soil Quality Guidelines for the Protection of Environmental and Human Health $\left(\mathrm{Pb} 58.7 \mathrm{mg} \mathrm{kg}^{-1}\right.$ and $\mathrm{Zn}$
$144 \mathrm{mg} \mathrm{kg}^{-1}$ ) but $\mathrm{Sn}$ concentration was higher than standard. In addition, the measured concentrations of these metals were compared with Sediment Quality Guidelines (SQGs) of Threshold Effects Concentration level (TEC) and Sediment quality in coastal and found that the metal concentration of this study was relatively higher than SQGs and TEC standards.

TABLE I: PhySIO-CHEMICAL PROPERTIES OF SEDIMENT CORE SAMPLES

\begin{tabular}{|c|c|c|c|c|c|c|}
\hline \multirow{3}{*}{$\begin{array}{c}\text { Depth } \\
\text { (cm) }\end{array}$} & \multicolumn{3}{|c|}{ Core A } & \multicolumn{3}{|c|}{ Core B } \\
\hline & \multicolumn{3}{|c|}{ Parameters } & \multicolumn{3}{|c|}{ Parameters } \\
\hline & pH & ORP (mV) & $\mathrm{EC}(\boldsymbol{\mu S} / \mathbf{c m})$ & pH & ORP (mV) & $\mathrm{EC}(\boldsymbol{\mu S} / \mathbf{c m})$ \\
\hline $1-5$ & $7.2 \pm 0.32^{\mathrm{a}}$ & $17.6 \pm 5.7^{\mathrm{d}}$ & $1117 \pm 13^{\mathrm{i}}$ & $8.5 \pm 0.01^{\mathrm{e}}$ & $47.9 \pm 16.9^{\mathrm{h}}$ & $752 . \pm 46.1^{\mathrm{c}}$ \\
\hline $6-10$ & $7.7 \pm 0.09^{b}$ & $-35.1 \pm 6.1^{d}$ & $967 \pm 69.5^{\mathrm{h}}$ & $8.6 \pm 0.06^{\mathrm{e}}$ & $-37.6 \pm 0.62^{\mathrm{g}, \mathrm{h}}$ & $1092 \pm 230^{\mathrm{c}}$ \\
\hline $11-15$ & $8.0 \pm 0.11^{\mathrm{c}}$ & $-51.3 \pm 1.0^{\mathrm{d}}$ & $1017 \pm 82^{\mathrm{h}}$ & $8.7 \pm 0.06^{\mathrm{e}}$ & $41.9 \pm 0.29^{\mathrm{g}, \mathrm{h}}$ & $979 \pm 109^{b}$ \\
\hline $16-20$ & $8.1 \pm 0.04^{\mathrm{d}}$ & $-115 \pm 5.4^{\mathrm{c}, \mathrm{d}}$ & $789 \pm 46.8^{h}$ & $8.6 \pm 0.01^{\mathrm{d}, \mathrm{e}}$ & $70.9 \pm 3.2^{\mathrm{f}, \mathrm{g}, \mathrm{h}}$ & $843 \pm 92.2^{b}$ \\
\hline $21-25$ & $8.2 \pm 0.02^{\mathrm{d}, \mathrm{e}}$ & $32 \pm 4.4^{\mathrm{c}, \mathrm{d}}$ & $1045 \pm 39.9^{\mathrm{g}, \mathrm{h}}$ & $8.5 \pm 0.07^{\mathrm{c}, \mathrm{d}, \mathrm{e}}$ & $106 \pm 2.6^{\mathrm{f}, \mathrm{g}}$ & $1040 \pm 24.8^{\mathrm{b}}$ \\
\hline $26-30$ & $8.4 \pm 0.02^{\mathrm{d}, \mathrm{e}, \mathrm{f}}$ & $43.2 \pm 3.7^{\mathrm{c}}$ & $1598 \pm 24.6^{\mathrm{g}, \mathrm{h}}$ & $8.5 \pm 0.08^{\mathrm{c}, \mathrm{d}, \mathrm{e}}$ & $89.5 \pm 5.6^{\mathrm{f}, \mathrm{g}}$ & $1338 \pm 243^{a, b}$ \\
\hline $31-35$ & $8.3 \pm 0.07^{\mathrm{e}, \mathrm{f}}$ & $-116 \pm 4.8^{b}$ & $1415 \pm 95.4^{\mathrm{f}, \mathrm{g}, \mathrm{h}}$ & $8.4 \pm 0.34^{\mathrm{b}, \mathrm{c}, \mathrm{d}, \mathrm{e}}$ & $91.7 \pm 2.6^{\mathrm{e}, \mathrm{f}}$ & $1666 \pm 69.5^{\mathrm{a}, \mathrm{b}}$ \\
\hline $36-40$ & $8.3 \pm 0.03^{\mathrm{f}}$ & $-116 \pm 2.5^{b}$ & $1626 \pm 253.2^{\mathrm{f}, \mathrm{g}, \mathrm{h}}$ & $8.6 \pm 0.02^{\mathrm{b}, \mathrm{c}, \mathrm{d}, \mathrm{e}}$ & $79.1 \pm 4.9^{\mathrm{d}, \mathrm{e}, \mathrm{f}}$ & $1609 \pm 155^{\mathrm{a}, \mathrm{b}}$ \\
\hline $41-45$ & $8.4 \pm 0.03^{\mathrm{f}}$ & $-128 \pm 6.4^{b}$ & $1848 \pm 14.9^{\mathrm{e}, \mathrm{f}, \mathrm{g}}$ & $8.7 \pm 0.03^{\mathrm{b}, \mathrm{c}, \mathrm{d}, \mathrm{e}}$ & $76.2 \pm 6.0^{\mathrm{d}, \mathrm{e}, \mathrm{f}}$ & $1251 \pm 249^{\mathrm{a}, \mathrm{b}}$ \\
\hline $46-50$ & $8.7 \pm 0.05^{\mathrm{g}}$ & $-123 \pm 3.6^{b}$ & $1380 \pm 130^{\mathrm{e}, \mathrm{f}}$ & $8.5 \pm 0.04^{\mathrm{b}, \mathrm{c}, \mathrm{d}, \mathrm{e}}$ & $77.8 \pm 7.1^{\mathrm{d}, \mathrm{e}, \mathrm{f}}$ & $1598 \pm 154^{\mathrm{a}, \mathrm{b}}$ \\
\hline $51-55$ & $8.7 \pm 0.04^{\mathrm{g}, \mathrm{h}}$ & $-113 \pm 4.2^{\mathrm{b}}$ & $1926 \pm 19.8^{\mathrm{e}, \mathrm{f}}$ & $8.5 \pm 0.13^{\mathrm{b}, \mathrm{c}, \mathrm{d}, \mathrm{e}}$ & $89.1 \pm 6.9^{\mathrm{d}, \mathrm{e}, \mathrm{f}}$ & $1356 \pm 229^{\mathrm{a}, \mathrm{b}}$ \\
\hline $56-60$ & $8.7 \pm 0.09^{\mathrm{g}, \mathrm{h}, \mathrm{i}}$ & $-131 \pm 2.8^{b}$ & $1131 \pm 218^{\mathrm{d}, \mathrm{e}}$ & $8.5 \pm 0.09^{\mathrm{b}, \mathrm{c}, \mathrm{d}, \mathrm{e}}$ & $100 \pm 5.8^{\mathrm{d}, \mathrm{e}}$ & $1389 \pm 94.4^{\mathrm{a}, \mathrm{b}}$ \\
\hline $61-65$ & $8.8 \pm 0.05^{\mathrm{g}, \mathrm{h}, \mathrm{i}}$ & $-124 \pm 6.9^{a}$ & $2148 \pm 34.8^{\mathrm{c}, \mathrm{d}, \mathrm{e}}$ & $8.1 \pm 0.18^{\mathrm{b}, \mathrm{c}, \mathrm{d}, \mathrm{e}}$ & $122 \pm 11.1^{\mathrm{d}, \mathrm{e}}$ & $1190 \pm 156^{\mathrm{a}, \mathrm{b}}$ \\
\hline $66-70$ & $8.8 \pm 0.08^{\mathrm{g}, \mathrm{h}, \mathrm{i}}$ & $-68.2 \pm 2^{\mathrm{a}}$ & $2066 \pm 53^{\mathrm{b}, \mathrm{c}, \mathrm{d}, \mathrm{e}}$ & $8.4 \pm 0.06^{\mathrm{b}, \mathrm{c}, \mathrm{d}, \mathrm{e}}$ & $119 \pm 5.1^{\mathrm{d}, \mathrm{e}}$ & $2495 \pm 119^{\mathrm{a}, \mathrm{b}}$ \\
\hline $71-75$ & $8.8 \pm 0.01^{\mathrm{g}, \mathrm{h}, \mathrm{i}}$ & $-35.9 \pm 12^{\mathrm{a}}$ & $2167 \pm 248^{\mathrm{a}, \mathrm{b}, \mathrm{c}, \mathrm{d}}$ & $8.6 \pm 0.08^{\mathrm{b}, \mathrm{c}, \mathrm{d}, \mathrm{e}}$ & $116 \pm 1.1^{\mathrm{d}}$ & $2481 \pm 188^{\mathrm{a}, \mathrm{b}}$ \\
\hline $76-80$ & $8.9 \pm 0.03^{\text {h.i }}$ & $-49.1 \pm 5.2^{\mathrm{a}}$ & $2041 \pm 159^{\mathrm{a}, \mathrm{b}, \mathrm{c}, \mathrm{d}}$ & $8.7 \pm 0.04^{\mathrm{b}, \mathrm{c}, \mathrm{d}}$ & $102 \pm 2.1^{\mathrm{d}}$ & $1070 \pm 24.8^{\mathrm{a}, \mathrm{b}}$ \\
\hline $81-85$ & $8.8 \pm 0.03^{\mathrm{i}}$ & $-59.9 \pm 16^{\mathrm{a}}$ & $2134 \pm 69.5^{\mathrm{a}, \mathrm{b}, \mathrm{c}}$ & $8.6 \pm 0.08^{b, c}$ & $95.5 \pm 5.1^{\mathrm{c}}$ & $977 \pm 24.8^{\mathrm{a}, \mathrm{b}}$ \\
\hline $86-90$ & $9.1 \pm 0.03^{\mathrm{i}, \mathrm{j}}$ & $55.3 \pm 1.7^{\mathrm{a}}$ & $2626 \pm 102^{\mathrm{a}, \mathrm{b}}$ & $8.5 \pm 0.09^{b}$ & $71 \pm 7.4^{\mathrm{c}}$ & $1256 \pm 38.7^{\mathrm{a}, \mathrm{b}}$ \\
\hline $91-95$ & $8.9 \pm 0.07^{\mathrm{i} . \mathrm{j}}$ & $59.9 \pm 2.3^{\mathrm{a}}$ & $1731 \pm 243^{\mathrm{a}}$ & $8.4 \pm 0.10^{\mathrm{a}}$ & $86 \pm 0.88^{b}$ & $993 \pm 114^{\mathrm{a}}$ \\
\hline $96-100$ & $8.9 \pm 0.06^{\mathrm{j}}$ & $59.7 \pm 2.8^{\mathrm{a}}$ & $1457 \pm 174^{\mathrm{a}}$ & $8.2 \pm 0.19^{\mathrm{a}}$ & $-117 . \pm 1.9^{\mathrm{a}}$ & $1054 \pm 54.6^{\mathrm{a}}$ \\
\hline Max & 9.1 & 59.9 & 2626 & 8.7 & 122 & 2495 \\
\hline Min & 7.2 & -131 & 789 & 8.1 & -117 & 752 \\
\hline Mean & 8.5 & -50 & 1612 & 8.5 & 73.9 & 1321 \\
\hline
\end{tabular}

TABLE II: CONCENTRATIONS OF ZINC (ZN), LEAD (PB) AND TIN (SN) IN THE STUDIED CORES

\begin{tabular}{|c|c|c|c|c|c|c|c|c|}
\hline \multirow{3}{*}{$\begin{array}{c}\text { Depth } \\
\text { (cm) }\end{array}$} & \multicolumn{4}{|c|}{ Core A } & \multicolumn{4}{|c|}{ Core B } \\
\hline & \multicolumn{4}{|c|}{ Concentrations $\left(\mathrm{mg} \mathrm{kg}^{-1}\right)$} & \multicolumn{4}{|c|}{ Concentrations $\left(\mathrm{mg} \mathrm{kg}^{-1}\right)$} \\
\hline & $\mathbf{Z n}$ & $\mathbf{P b}$ & Sn & Al & $\mathbf{Z n}$ & $\mathbf{P b}$ & Sn & Al \\
\hline $1-5$ & $65.4 \pm 2.1$ & $12.7 \pm 1.6$ & $99.1 \pm 0.05$ & $15429 \pm 127$ & $144 \pm 6.5$ & $11.1 \pm 0.51$ & $89.9 \pm 0.06$ & $21233 \pm 215$ \\
\hline $6-10$ & $50.9 \pm 3.8$ & $17.5 \pm 6.1$ & 107. \pm 0.06 & $17664 \pm 147$ & $95.7 \pm 3.5$ & $52.5 \pm 2.5$ & $105 \pm 0.10$ & $21986 \pm 795$ \\
\hline $11-15$ & $60.7 \pm 1.1$ & $18.1 \pm 0.2$ & $98.1 \pm 0.06$ & $20684 \pm 213$ & $59.5 \pm 1.6$ & $30.5 \pm 2.1$ & $113 \pm 0.07$ & $24873 \pm 192$ \\
\hline $16-20$ & $46.5 \pm 6.1$ & $20.2 \pm 2.1$ & $111 \pm 0.07$ & $23321 \pm 111$ & $64.2 \pm 7.1$ & $38.2 \pm 2.3$ & $118 \pm 0.01$ & $18387 \pm 444$ \\
\hline $21-25$ & $46.5 \pm 3.4$ & $22.4 \pm 3.7$ & $126 \pm 0.01$ & $29293 \pm 322$ & $68.6 \pm 5.3$ & $42.5 \pm 7.3$ & $113 \pm 0.08$ & $19429 \pm 408$ \\
\hline $26-30$ & $88.0 \pm 3.3$ & $25.3 \pm 1.3$ & $111 \pm 0.02$ & $22874 \pm 544$ & $69.9 \pm 9.3$ & $45.9 \pm 3.4$ & $128 \pm 0.08$ & $35683 \pm 932$ \\
\hline $31-35$ & $54.4 \pm 4.5$ & $23.9 \pm 2.6$ & $129 \pm 0.04$ & $26191 \pm 179$ & $89.9 \pm 1.1$ & $39.1 \pm 1.9$ & $123 \pm 0.04$ & $43681 \pm 794$ \\
\hline $36-40$ & $62.9 \pm 1.1$ & $27.1 \pm 8.7$ & $162 \pm 0.13$ & $24981 \pm 133$ & $95.1 \pm 5.5$ & $58.7 \pm 2.8$ & $77.5 \pm 0.03$ & $46225 \pm 753$ \\
\hline $41-45$ & $66.9 \pm 5.1$ & $35.9 \pm 5.3$ & $150 \pm 0.04$ & $37466 \pm 614$ & $112 \pm 10.1$ & $54.5 \pm 2.1$ & $92.1 \pm 0.11$ & $41144 \pm 149$ \\
\hline $46-50$ & $69.1 \pm 5.8$ & $33.0 \pm 4.6$ & $167 \pm 0.06$ & $36681 \pm 347$ & $98.6 \pm 5.2$ & $36.0 \pm 7.4$ & $106 \pm 0.04$ & $56974 \pm 307$ \\
\hline $51-55$ & $71.1 \pm 9.1$ & $35.7 \pm 3.1$ & $49.9 \pm 1.85$ & $34735 \pm 502$ & $111 \pm 6.5$ & $49.1 \pm 1.3$ & $110 \pm 0.05$ & $30058 \pm 302$ \\
\hline $56-60$ & $76.1 \pm 4.2$ & $37.0 \pm 7.0$ & $156 \pm 0.03$ & $35782 \pm 459$ & $75.2 \pm 3.4$ & $36.2 \pm 1.3$ & $118 \pm 0.05$ & $66034 \pm 324$ \\
\hline $61-65$ & $59.7 \pm 1.1$ & $27.2 \pm 1.5$ & $152 \pm 0.15$ & $29400 \pm 638$ & $82.9 \pm 7.3$ & $45.3 \pm 3.2$ & $111 \pm 0.03$ & $72306 \pm 382$ \\
\hline $66-70$ & $50.9 \pm 2.7$ & $44.5 \pm 1.5$ & $139 \pm 0.17$ & $29260 \pm 576$ & $86.4 \pm 1.2$ & $37.2 \pm 4.9$ & $127 \pm 0.04$ & $50962 \pm 481$ \\
\hline $71-75$ & $45.4 \pm 1.4$ & $31.0 \pm 4.7$ & $129 \pm 0.08$ & $34867 \pm 151$ & $83.7 \pm 4.1$ & $30.8 \pm 8.5$ & $124 \pm 1.28$ & $60584 \pm 759$ \\
\hline
\end{tabular}




\begin{tabular}{lllllllll}
$76-80$ & $62.3 \pm 8.3$ & $32.4 \pm 3.9$ & $145 \pm 0.06$ & $32916 \pm 490$ & $61.6 \pm 0.7$ & $16.4 \pm 3.6$ & $153 \pm 0.05$ & $56501 \pm 908$ \\
$81-85$ & $79.9 \pm 2.4$ & $26.7 \pm 3.5$ & $136 \pm 0.12$ & $29568 \pm 395$ & $69.7 \pm 1.2$ & $9.6 \pm 3.1$ & $109 \pm 0.3$ & $51683 \pm 106$ \\
$86-90$ & $70.9 \pm 5.3$ & $16.8 \pm 1.6$ & $146 \pm 0.06$ & $25600 \pm 197$ & $79.5 \pm 1.2$ & $14.5 \pm 1.1$ & $133 \pm 0.07$ & $45673 \pm 284$ \\
$91-95$ & $85.3 \pm 2.1$ & $14.6 \pm 1.9$ & $148 \pm 0.16$ & $22083 \pm 538$ & $74.2 \pm 6.1$ & $13.8 \pm 2.4$ & $121 \pm 0.11$ & $69066 \pm 338$ \\
$96-100$ & $58.8 \pm 1.9$ & $13.4 \pm 0.7$ & $153 \pm 0.11$ & $18287 \pm 224$ & $78.1 \pm 5.4$ & $17.9 \pm 2.5$ & $105 \pm 0.08$ & $33630 \pm 873$ \\
Max & $\mathbf{8 8 . 0}$ & $\mathbf{4 4 . 5}$ & $\mathbf{1 6 7}$ & $\mathbf{3 7 4 6 6}$ & $\mathbf{1 4 4}$ & $\mathbf{5 8 . 7}$ & $\mathbf{1 5 3}$ & $\mathbf{7 2 3 0 6}$ \\
Min & $\mathbf{4 5 . 4}$ & $\mathbf{1 2 . 7}$ & $\mathbf{4 9 . 9}$ & $\mathbf{1 5 4 2 9}$ & $\mathbf{5 9 . 9}$ & $\mathbf{9 . 6}$ & $\mathbf{7 7 . 5}$ & $\mathbf{1 8 3 8 7}$ \\
\hline \hline
\end{tabular}

TABLE III: SEDIMENT QUALITY FROM THE NATIONAL AND INTERNATIONAL STANDARDS

\begin{tabular}{|c|c|c|c|c|}
\hline \multirow[t]{2}{*}{ Standards } & \multicolumn{3}{|c|}{$\begin{array}{c}\text { Concentrations } \\
\left(\mathrm{mg} \mathrm{kg}^{-1}\right)\end{array}$} & \multirow[t]{2}{*}{ References/years } \\
\hline & Zn & $\mathbf{P b}$ & Sn & \\
\hline $\begin{array}{l}\text { 1. Soil Quality Guidelines for the Protection of Environmental } \\
\text { and Human Health } \\
\text { 2. Sediment Quality Guidelines: SQGs Threshold Effects } \\
\text { Concentration level (TEC) }\end{array}$ & $\begin{array}{l}200 \\
121\end{array}$ & $\begin{array}{r}140 \\
35.8\end{array}$ & $\begin{array}{l}50 \\
-\end{array}$ & $\begin{array}{l}\text { Canadian Council of Ministers of the } \\
\text { Environment, } 1999 \text { [28] } \\
\text { Department of pollution control, } 2012 \text { [29] }\end{array}$ \\
\hline $\begin{array}{l}\text { 3. Sediment quality in coastal } \\
\text { (to prevent marine benthic) }\end{array}$ & 102 & 52 & - & Department of pollution control, 2015 [30] \\
\hline 4. This study & 144 & 58.7 & 167 & This study, 2017 \\
\hline
\end{tabular}

\section{Geo-Accumulation Index $\left(I_{\text {geo }}\right)$ Evaluation of Heavy Metals}

The calculated $\mathrm{I}_{\mathrm{geo}}$ values for $\mathrm{Zn}$ in core A showed the values of less than zero (-1.40 to -0.45$)$ which indicated unpolluted condition of the sediments. In addition, the $\mathrm{I}_{\text {geo }}$ values for $\mathrm{Zn}$ in core $\mathrm{B}$ are ranged from -1.01 to 0.26 indicated unpolluted to moderately polluted level of the sediments. In contrast, the $\mathrm{I}_{\text {geo }}$ values for $\mathrm{Pb}$ were observed to be from -1.24 to 0.57 and -1.64 to 0.97 in core A and core B, respectively indicated that the sediment was unpolluted to moderately polluted level. Therefore, it is suggested that almost all of the sediment samples in this study were not contaminated or moderately contaminated with $\mathrm{Zn}$ and $\mathrm{Pb}$. The low $I_{\text {geo }}$ values were found in other studies. For example, $\mathrm{Pb}$ was found to be unpolluted/moderately polluted in Bangpakong estuary, Chachoengsao province [31] and the sediments at the inner Gulf of Thailand were found to be moderately polluted with $\mathrm{Pb}$ [32].

\section{Enrichment Factor (EF) Evaluation of Heavy Metals}

The enrichment factor (EF) is a useful tool for differentiating the man-made and natural sources of metal contamination [33]. This evaluating technique is carried out by normalizing the metal concentration based on geological characteristics of [34]. Al has been widely used for normalizing the metal concentration in sediments because it is a major metal element in the earth crust and not affected by man-made factors [35]. In this study, the EF profiles for $\mathrm{Zn}$ in core A and B are ranged from 2.1 to 6.9 and 1.6 to 6.2 , respectively. These results indicated that sediment samples are minimal to significant enrichment. The EF values of $\mathrm{Pb}$ in Core A and B ranged from 3.4 to 9.8 and 1.9 to 6.9 , respectively. It also indicates that sediment samples are minimal to significant enrichment from human activity in the studied area. The human activities from local contribution can be influenced the pollution level in this study area. In addition, it was observed that $\mathrm{Zn}$ is enriched in the upper layers as compared to the lower layers of core sediments. However, $\mathrm{Pb}$ was observed to be enriched in the lower layers
(40 to $75 \mathrm{~cm}$ ) as compared to the upper layers of sediment cores. These results are consistent with the research in the inner Gulf of Thailand as they found the significant $\mathrm{Pb}$ enrichment of sediments by anthropogenic activities [32].

\section{CONCLUSIONS}

In conclusion, this study shows that the concentrations of the heavy metals in Phuket bay were ranged over following intervals: Sn 49.9 to $167 \mathrm{mg} \mathrm{kg}^{-1}, \mathrm{~Pb} 9.6$ to $58.7 \mathrm{mg} \mathrm{kg}^{-1}$ and $\mathrm{Zn} 45.4$ to $144 \mathrm{mg} \mathrm{kg}^{-1}$ that are found to be below the Soil Quality Guidelines for the Protection of Environmental and Human Health except for tin ( $\mathrm{Sn}$ ) metal ( $\mathrm{Sn}, \mathrm{Pb}$ and $\mathrm{Zn}$ : 50, 140 and $200 \mathrm{mg} \mathrm{kg}^{-1}$, respectively). While the measured concentrations of these metals were higher than Sediment Quality Guidelines: SQGs Threshold Effects Concentration level (TEC) (Pb and $\mathrm{Zn}: 35.8,121 \mathrm{mg} \mathrm{kg}^{-1}$, respectively) and Sediment quality in coastal $\left(\mathrm{Pb}\right.$ and $\mathrm{Zn}: 52,102 \mathrm{mg} \mathrm{kg}^{-1}$, respectively). The contamination levels of the heavy metals by calculated $I_{\text {geo }}$ values suggested that almost all of the sediment samples in this study were either not contaminated or moderately contaminated with $\mathrm{Zn}$ and $\mathrm{Pb}$ metals ( -1.40 to 0.26 and -1.24 to 0.97 , respectively), and the sediment samples are minimal to significant enrichment from anthropogenic activity (the EF values for $\mathrm{Pb}$ and $\mathrm{Zn}: 1.6$ to 6.2 and 2.1 to 6.9 , respectively). It was suggested that the anthropogenic activities may be from local contribution and influence of urbanization recently. However, since sediments can accumulate for heavy metals in the aquatic system, their potential risks to the environment must be considered.

\section{ACKNOWLEDGMENT}

The authors thank the Office of Higher Education Commission (OHEC) and the S\&T Postgraduate Education and Research Development Office (PERDO) for the financial support of the Research Program and thank the Ratchadaphiseksomphot Endowment Fund, Chulalongkorn University for the Research Unit. We would like to express our sincere thanks to the Environmental Research Institute 
(ERIC) and the Center of Excellence on Hazardous Substance Management (HSM) Chulalongkorn University for their invaluable supports in terms of facilities and scientific equipment. Special thanks to Faculty of Technology and Environment, Prince of Songkla University, Phuket Campus for a part of financial support.

\section{REFERENCES}

[1] E. Callender, "Heavy metals in environment-historical trends," Elsevier-Pergamon, pp. 67-106, 2005.

[2] L. Bruggemann, A. Paschke, B. Daus, and H. Weiss, "Characterization of sediments in an 405 abandoned mining area; a case study of Mansfield region," Ger. Environ. Geol, vol. 45, pp. 818-833, 2004.

[3] J. O. Nriagu, "Global metal pollution: poisoning the biosphere," Environ Sci Policy Sustain Dev, vol. 32, pp. 7-33, 1990.

[4] R. Yu, X. Yuan, Y .Zhao, G. Hu, and X. Tu, "Heavy metal pollution in intertidal sediment from Quanzhou Bay, China" Journal of Environment Science, vol. 3, pp. 125-142, 2008.

[5] N. Khongkwan, Mining in Thailand, PR Content Center, Bangkok, 2015.

[6] T. Suteerasak and T. Bhongsuwan, "Contamination of heavy metals Al, As, $\mathrm{Cu}, \mathrm{Cr}, \mathrm{Mn}, \mathrm{Ni}, \mathrm{Pb}, \mathrm{Sn}, \mathrm{Zn}$ and Fe in sediment from Bang-Yai River in Phuket Province," Research and Development KMUTT J., vol. 31, pp. 765-779, October-December, 2008.

[7] The Department of mineral resources, Classification of Geology and Mineral Resources Management Phuket Province, Bangkok, 2013.

[8] Navy Hydrographic Department, Tidal Sea Level of Phuket Province, Phuket, Thailand, 2017.

[9] US EPA, Method 3052 Microwave Assisted Acid Digestion of Siliceous and Organically Based Matrices, 1996.

[10] National Research Council Canada MESS-4: Marine Sediment Reference Material for Trace Metals and other Constituents, Canada, 2014.

[11] P. Woitke, J. Wellmitz, D. Helm, P. Kube, P. Lepom, and P. Litheraty, "Analysis and assessment of heavy metal pollution in suspended solids and sediments of the river Danube," Chemosphere, vol. 51, pp. 633-642, 2003.

[12] M. S. Garson, B. Young, A. H. G. Mitchell, and B. A. R. Tait, The Geology of the Tin Belt in Peninsular Thailand around Phuket, Phangnga, and Takua Pa, Natural Environment Research Council, Institute of Geological Sciences, London, 1975.

[13] The Department of pollution control, Report Set the Benchmark in Quality, Sediment, and Surface Water Sources, Office waste management and hazardous substances, Bangkok, 2012.

[14] G. Müller, "Index of geoaccumulation in sediments of the Rhine River," Geo J., vol. 2 pp. 109-118, 1969.

[15] C. Sukudom, M. Kaewnern, I. Wudtisin, T. Yoshikawa, Y. Okamoto, K. Watanabe, S. Ishikawa, and J. Salaenoi, "Organic contents and $\mathrm{pH}$ profiles of sediments in cockle farm at Bandon Bay, Surat Thani Province," KHON KAEN AGR J., vol.43, pp. 265-276, 2015.

[16] U. Pravin et al., "Assessing the physico-chemical parameters of sediment ecosystem of vasai creek at Mumbai, India," Marine Science, vol. 1, pp. 22-29, 2011.

[17] G. Sposito, The Chemistry of Soils, Oxford University Press, New York, 1989.

[18] P. Kelderman and A. A. Osman, "Effect of redox potential on heavy metal binding forms in polluted canal sediments in delft (The Netherlands)," Water Res, vol. 41, pp. 4251-4261, 2007.

[19] W. Salomons, "Environmental impact of metals derived from mining activities: processes, predictions, prevention," J. Geochem. Explor, vol. 52, pp. 5-23, 1995.

[20] J. Nemecek, L. Smolikova, and M. Kutilek, Pedologie a Paleopedologie Academia, p. 552, 1990.

[21] A. Kabata and H. Pendias, Trace Elements in Soils and Plants, 3rd edition, CRC Press, Florida, 2001.
[22] W. Wisawapipat, "Remediation technologies of heavy metal contaminated soils using phosphate materials," KHON KAEN AGR. J., vol. 40, pp. 373-378, 2012.

[23] N. Aunjangwang, "Contamination of arsenic and lead in sediment of U-Taphao canal," M.S. thesis science in marine and coastal resources management, Prince of Songkla University, Songkla, Thailand, 2013.

[24] J. Nouri, B. J. Alloway and P. J. Peterson, "Forms of heavy metals in sewage sludge and soil amended with sludge," PakJ Biol Sci, vol. 4, pp. 1460-1465, 2001.

[25] P. Kathuli, "Soil salinization in selected irrigation schemes in Taveta Sub County, Kenya," East Africa Agriculture and Forestry Journal, 2014.

[26] W. T. Ward, G. McTainsh, D. McGarry, and K. J. Smith, "The soils of the agricultural research station at 'Myall Vale', near Narrabri, NSW, with data analysis by fuzzy k-means," CSIRO Technical Report 21/99, 1999.

[27] W. Seatang, W. Laongmanee, B. Paibulkichakul, and C Paibulkichakul, "Soil electrical conductivity at Chanthaburi Estuary during winter and rainy seasons," KHON KAEN AGR. J., vol. 42 suppl. $1,2014$.

[28] Canadian Council of Ministers of the Environment, Canadian Sediment Quality Guidelines for the Protection of Aquatic Life: Summary Tables Updated. In: Canadian Environmental Quality Guidelines 1999, Canadian Council of Ministers of the Environment, Winnipeg, Canada, 2002.

[29] The Department of pollution controls, Sediment Quality Guidelines (SQGs) of Threshold Effects Concentration level (TEC), Bangkok, 2012.

[30] Department of pollution controls, Sediment quality in coastal, Bangkok, Thailand, 2015

[31] W. Thongra-ar, C. Musika, W. Wongsudawan, and A. Munhapon, "Distribution and accumulation of some heavy metals in mangrove sediments of Ban Laemchabang Community, Chon Buri Province," Burapha University International Conference 2015, Proceedings of the Burapha University International Conference 2015, July, pp. 780-788, 2015.

[32] P. Mingkwan, M. Suksomjit, and S. Jiewjareun, The Quality of Sediment in the Gulf of Thailand after the Floods in 2012, Department of Pollution Control, Bangkok, 2012.

[33] J. Morillo, J. Usero, and I. Gracia, "Heavy metal distribution in marine sediments from the southwest coast of Spain," Chemosphere, vol. 55, pp. 431-442, 2004.

[34] W. C. Chiu, F. C. Chih, and D. D. Cheng, "Distribution and enrichment evaluation of cadmium in the sediments of Canon River Mouth, Taiwan," Energy Procedia, vol. 16, pp. 895 - 900, 2012.

[35] C. W. Chen, C. M. Kao, C. F. Chen, and C. D. Dong, "Distribution and accumulation of heavy metals in the sediments of Kaohsiung Harbor, Taiwan," Chemosphere, vol. 66, pp. 1431-1440, 2007.

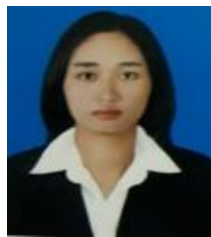

Kaimook Jaileak was born in Phuket, Thailand in April, 1995. She is a master student in technology and environment at Prince of Songkla University, Phuket campus in Phuket, Thailand. She got her bachelor degree in 2016 from Prince of Songkla University, Phuket campus in Phuket, Thailand. Her major is environmental technology and management.

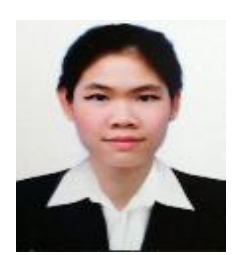

Pensiri Akkajit was born in Thailand, October, 26 1982. She got High School Certificate from Burwood Girls' High School, Sydney, Australia and was graduated from Chulalongkorn University, Thailand for the doctoral of philosophy (in 2012) and the master of science (in 2007) in environmental management (international program). She received her bachelor's degree in environmental technology (international program) from Sirindhorn International Institute of Technology (SIIT), Thammasat University, Thailand. She is now a lecturer at Faculty of Technology and Environment, Prince of Songkla University, Phuket Campus, Thailand. 